\title{
ARTIGO
}

DOI: $10.22481 /$ praxis.v14i28.3466

\section{PROCESSOS, PECULIARIDADES E PRÁTICA DOCENTE NA OFERTA EDUCATIVA NO SISTEMA PRISIONAL DO AMAZONAS}

\author{
PROCESSES, PECULIARITIES AND TEACHER PRACTICE IN THE EDUCATIONAL \\ OFFER IN THE PRISON SYSTEM OF AMAZONAS
}

\author{
PROCEDIMIENTOS, PECULIARIDADES Y PRACTICA DOCENTE EN LA OFERTA \\ EDUCATIVA EN EL SISTEMA PRISIONAL DE AMAZONAS
}

Fabiane Maia Garcia

Universidade Federal do Amazonas - Brasil

Thays Coelho de Araújo

Universidade Federal do Amazonas - Brasil

Poline Melo dos Santos

Universidade Federal do Amazonas - Brasil

\begin{abstract}
Resumo
A presente pesquisa apresenta os resultados de dois estudos. O primeiro resulta de um TCC em Pedagogia e se debruça sobre as ações e particularidades da prática docente, tomadas como conjunto de saberes necessários aos desafios que caracterizam o ser professor da educação de jovens e adultos em uma sala de aula do sistema prisional. A segunda pesquisa aborda as políticas linguísticas que envolvem o letramento e o ensino de Língua Portuguesa no contexto prisional amazonense. Desse modo, objetivou analisar as ações que envolvem a leitura e a escrita como propostas políticas de remição de apenados pelos estudos. Teoricamente, centra-se nos preceitos da Política Linguística pensada por Calvet (2007), Orlandi (2007), Teixeira (2014) e nas concepções dos Novos Estudos do Letramento (NEL), apontadas por Kleiman (1995; 2000), Street (2003), Lillis (2003). As duas pesquisas adotaram o paradigma qualitativo de pesquisa, com convergência no uso de documentos institucionais, bem como utilizaram o procedimento técnico da pesquisa bibliográfica. Assim, na primeira pesquisa, as análises apontam a prática educativa como parte de um conjunto de ações definidas pelas autoras com reinserção educativa, enquanto que a segunda aponta que a proposta de remição do sujeito preso, por meio das práticas dominantes de letramento, necessita ir além do pretexto da diminuição de pena, necessita, portanto, de mobilizações políticas e linguísticas que visem a diminuição do viés utilitarista do letramento.
\end{abstract}

Palavras-chave: Educação; Reinserção educativa; Leitura; Sistema Prisional amazonense.

\section{Abstract}

The present research presents the results of two studies. The first one results from a course conclusion paper in Pedagogy and focuses on the actions and particularities of teaching practice, taken with a set 
of knowledge necessary to the challenges that characterize being a teacher of youth and adult education in a prison system classroom. The second research deals with the linguistic policies that involve literacy and Portuguese language teaching in the Amazon prison context. In this way, the objective was to analyze the actions involving reading and writing as political proposals for the remission of their crimes through studies. Theoretically, it focuses on the precepts of Linguistic Policy thought by Calvet (2007), Orlandi (2007), Teixeira (2014) and in the conceptions of the New Literature Studies (NEL), pointed out by Kleiman (1995; 2000), Street (2003), Lillis (2003). Both researches were based on interpretation criteria, with the adoption of the qualitative research paradigm, with convergence in the use of institutional documents, as well as with the technical procedure of bibliographic research. Thus, in the first research the analyzes points to the educational practice as part of a set of actions defined by the authors with educational reintegration, while the second one points out that the proposal of remission of the arrested student, through the dominant practices of literacy, needs to go in addition to the pretext of diminishing punishment, therefore requires political and linguistic mobilizations aimed at reducing opportunistic use of literacy.

Keywords: Education; Educational reintegration; Reading; Prison system of Amazonas.

\section{Resumen}

La presente investigación presenta los resultados de dos estudios. El primero resulta de un TCC (trabajo de conclusión de curso) en Pedagogía y se centra en las acciones y particularidades de la práctica docente, consideradas como un conjunto de saberes necesarios a los desafíos que caracterizan el hecho ser profesor de la educación de jóvenes y adultos en una sala de clase del sistema penitenciario. El segundo estudio se ocupa de las políticas lingüísticas que involucran la alfabetización y la enseñanza del idioma portugués en contexto penitenciario del Amazonas. De ese modo, el objetivo se enfocó en analizar las acciones que envuelven la lectura y la escritura como propuestas políticas de remisión de apenados por los estudios. En el caso de los países de la Unión Europea (UE), los Estados miembros de la Unión Europea (UE), Lillis (2003). Las dos encuestas adoptaron el paradigma cualitativo de investigación, con convergencia en el uso de documentos institucionales, así como utilizaron el procedimiento técnico de la investigación bibliográfica. Así, en la primera investigación, los análisis apuntan a la práctica educativa como parte de un conjunto de acciones definidas por las autoras con reinserción educativa, mientras que la segunda aborda que la propuesta de remisión del sujeto preso, por medio de las prácticas dominantes del alfabetismo, además del pretexto de la disminución de la pena, necesita, por lo tanto, de movilizaciones políticas y linguiísticas que apunte a la disminución del sesgo utilitarista del alfabetismo.

Palabras clave: Educación; Reinserción educativa; lectura; Sistema Prisional amazonense.

\section{Introdução}

O presente trabalho corresponde a dois processos de análise da temática da Educação em sua oferta no sistema prisional do Amazonas. Partem da concepção da educação como direito fundamental a que toda pessoa tem o direito como assegura o Art. 26 da Declaração Universal dos Direitos Humanos. As pesquisas se inserem no contexto da educação brasileira que também marcou em 2017, os dez primeiros anos do projeto "Educando para a liberdade: trajetória, debates e proposições de um projeto para a educação nas prisões brasileiras" da 
UNESCO, do Ministério da Justiça e Ministério da Educação. Do mesmo modo, o estudo também é parte de um cenário de barbárie, em que os presidiários se digladiaram, destruindo grande parte das instalações de um presidio ${ }^{1}$. Os estudos têm por base uma revisão bibliográfica e teórica, que se amplia a partir da análise documental e de registros de observações diretas da prática docente, como no caso da primeira pesquisa desenvolvida ao final da formação profissional de Graduação como um Trabalho de Conclusão do Curso de Licenciatura em Pedagogia. Assim, o primeiro resultado tem como escopo a educação de estudantes privados de liberdade, na Escola Estadual Giovanni Figliuolo, no âmbito da Unidade Prisional Semiaberto Feminina (UPSF) na zona urbana de Manaus. Enquanto a segunda pesquisa, integra-se às propostas do Grupo de pesquisa Observatório de Línguas, que faz parte de investigações realizadas por pós-graduandos do Programa de Pós-Graduação em Letras da Universidade Federal do Amazonas, na linha de pesquisa Políticas Linguísticas. Esse estudo também analisa a oferta educativa, mas amplia a discussão ao colocar em cena as políticas linguísticas que se desenvolvem na área do ensino de Língua Portuguesa no sistema prisional do Amazonas.

$\mathrm{Na}$ primeira pesquisa, a abordagem resulta de experiências formativas de uma estudante de Pedagogia, que foi motivada, inicialmente, por práticas desenvolvidas com adolescentes em um projeto educacional, ofertado pela Secretaria de Estado e Cultura (SEC), posteriormente aprimorada no interior da Universidade, com a disciplina Educação de Jovens e Adultos, e que, por fim, consolida-se no contato com a gestora da denominada "escola do presidio" na Disciplina de Gestão Escolar. O processo de investigação foi próprio dos processos e as ações realizadas nos semestres letivos de 2016/02 e 2017/01, na Disciplina de Trabalho de Conclusão de Curso (TCC) I e II, da Faculdade de Educação (FACED) da Universidade Federal do Amazonas (UFAM). A pesquisa analisou as ações e particularidades das práticas pedagógicas desenvolvidas no espaço da escola, buscando descrever os fundamentos legais e as políticas públicas que asseguram o direito de acesso à escolarização ao sujeito privado de liberdade presentes nos marcos legais, teóricos e outros normativos voltados à educação escolar no sistema prisional na esfera nacional e local.

A temática é abordada a partir de um conjunto de referenciais em que se destacam estudos de vários pesquisadores como Onofre (2007), Onofre e Julião (2013), Oliveira (1984), entre outros. A importância desta análise ampara-se na percepção de que a oferta educativa e a prática docente na educação escolar no sistema prisional apresentam desafios e

\footnotetext{
${ }^{1}$ Após a morte de inúmeros presidiários em janeiro de 2017, o único local que não sofreu qualquer tipo de ataque foi o destinado ao funcionamento da escola.
} 
complexidades ainda desconhecidas pela maioria dos profissionais da educação em formação no Amazonas. De forma complementar, a análise da literatura e dos normativos, a pesquisa considerou os registros do diário de campo como estratégia funcional para explicitar a identificação e caracterização das principais práticas do professor na educação escolar no sistema prisional. Prática docente que consiste num resgate educativo, que tem como desafio a escolarização do sujeito que a sociedade julgou como um indivíduo que deve permanecer na prisão até seu possível retorno à liberdade. Por fim, nesse estudo é importante ressaltar a compreensão da sala de aula como campo da prática pedagógica dos professores da educação escolar no sistema prisional, pois é nesse espaço diferenciado que ocorre o entendimento das concepções sobre o trabalho docente na educação de jovens e adultos.

A segunda pesquisa, vinculada a um grupo de estudantes de Pós-Graduação, apresenta a discussão sobre as práticas de leitura e de escrita no processo de remição de pena. Desse modo, é parte do problema central do grupo que estuda as diferentes políticas pensadas para o ensino de línguas no Amazonas. Nesse quadro, a contribuição do segundo estudo centra-se no entendimento de umas dessas políticas linguísticas que se desenvolvem na área do ensino de Língua Portuguesa no sistema prisional do Amazonas. Assim sendo, investiga-se o Projeto "Encontro com a Leitura - Ler Liberta"2, concebido como uma política linguística, visto que permite a remição de pena por meio de práticas de letramento como a leitura e a escrita.

Ao investigar o projeto anteriormente descrito, o estudo busca colaborar com a compreensão das práticas de letramento no interior do processo da educação escolar no sistema prisional do Amazonas. Logo, a escolha é parte da necessidade de se caracterizar o trabalho de condução da leitura, bem como da escrita a partir de políticas educacionais aos jovens e adultos em situação de privação de liberdade. As práticas de leitura e escrita são parte de vários encaminhamentos legais que têm sido discutidos e implementados, no intuito de fortalecer uma política de âmbito nacional que assegure o direito à educação, previsto na Lei de Execuções Penais (Lei 7210/84). Para além da legislação, as reflexões amparam-se na abordagem teórica a respeito de Políticas Linguísticas, sob a luz de Calvet (2007), Orlandi (2007) e Oliveira (2003). Na sequência, a reflexão acerca da Educação no sistema prisional brasileiro considera três questões indissociáveis: políticas educacionais, linguísticas e prisionais. Nas três questões há destaque para o ensino de Língua Portuguesa no contexto

\footnotetext{
${ }^{2}$ Em 30 de maio de 2016, foi publicado o provimento no 272-CGJ/AM que institui o programa "Encontro com a Leitura - Ler Liberta", assinado pela Corregedoria-Geral de Justiça do Estado do Amazonas. (AMAZONAS, 2016, p.39). O referido programa é aplicado em forma de projeto pela Secretaria de Administração Penitenciária - SEAP
} 
prisional do Amazonas, no que se refere à aplicabilidade da Legislação Federal e ao Plano Estadual de Educação nas Prisões, com o desdobramento do Provimento $n^{\circ} 272 \mathrm{CCJ} / \mathrm{AM}$ que institui a remição de pena pela leitura.

De modo geral, nos dois estudos se apresenta a histórica exclusão e marginalização do direito à educação aos jovens e adultos, que não completaram o processo de escolarização na idade prevista pela legislação brasileira vigente e que acabam sendo o maior quantitativo da população carcerária no Brasil. Quando privados de liberdade, a educação assume outros significados que vão de um espaço tido como de liberdade (a sala de aula), e se estende a formas objetivas de remição de pena em busca de liberdade, como no caso da leitura. Assim, as análises resultam em pontos relevantes e necessários para a compreensão do trabalho do professor na sala de aula da educação escolar no sistema prisional, evidenciando os desafios que partem da prática docente para a liberdade, até a prática de leitura para remição da pena com as particularidades encontradas no âmbito do sistema prisional do Amazonas.

\section{Opção e percurso metodológico de dois estudos}

As pesquisas são de natureza qualitativa, na qual o objetivo é descritivo e explicativo, a partir do conjunto teórico e normativo escolhido para retratar a temática. No primeiro estudo, adotou-se o processo de observação direta, que resultou na estruturação de um diário de campo escrito como parte dos instrumentos usados na pesquisa. A prática do diário de observação direta figura como um modelo comum entre pesquisadores da área de antropologia, modelo esse adotado para dar ênfase na singularidade e peculiaridades, constituindo registros de tudo que se foi observado para posterior análise e interpretação, assim resultando num olhar único da temática pesquisada. Para Yin (2001), os resultados das observações são úteis para fornecer informações adicionais sobre estudo. Nesse contexto, o diário de campo serviu como importante fonte de e para o trabalho, pois enfatizou a relevância de descrever as informações e situações relatadas pela professora, fazendo necessário refletir sobre as dimensões que vão se revelando e a pontos inicialmente não previstos.

O primeiro estudo também se refere ao resultado da análise dos documentos e normativos que asseguram o direito do sujeito privado de liberdade, tais como: A Lei de Diretrizes e Bases da Educação Nacional (9394/96), Lei de Execução Penal (Lei 7210/84), Plano Nacional de Educação - PNE (Lei no 13.005/2014), Constituição Política do Estado do 
Amazonas e Plano Estadual de Educação nas Prisões - Amazonas (PEEP-AM), o Parecer CNE/CEB nº 4/2010 e a Resolução CNE/CEB n 2, de 19 de maio de 2010. O estudo foi realizado a partir dos documentos legais que garantem o direito ao acesso à educação, disponibilizados online, pela Gerência de Atendimento à Diversidade GAED/DEPPE/SEDUC e pela gestora da escola da Unidade Prisional Semiaberto Feminino (UPSF) do município de Manaus - Am. A análise articula-se aos conceitos vinculados aos direitos à assistência educacional que o Estado assegura ao sujeito privado de liberdade, tomando por base as estatísticas fornecidas por meio do Sistema de Informações Penitenciárias (Infopen), disponibilizadas pelo Departamento Penitenciário Nacional DEPEN (2014), além de notícias publicadas pelos meios de comunicação local.

A primeira pesquisa se configura em dois momentos. O primeiro ocorre a partir do levantamento das previsões legais que asseguram o direito ao acesso à educação especificados na Constituição Federal (CF 1988), na Lei de Diretrizes e Bases da Educação Nacional (9394/96), na Lei de Execução Penal (Lei 7210/84) e no Plano Estadual de Educação nas Prisões - Amazonas (PEEP-AM). No segundo momento, apresenta algumas análises resultantes do processo de observação direta a partir do contato com a gestão da escola e com os demais profissionais que se mostraram disponíveis em viabilizar as demandas apresentadas. Esse processo transcorreu a partir a existência de documento formalmente expedido pela Coordenação do Curso de Pedagogia, que solicitava autorização para a atividade de observação, citando os objetivos da pesquisa para o Trabalho de Conclusão de Curso com a explicação de como era orientado e acompanhado por um docente do Curso, presente constantemente nas dependências da escola como parte do processo de construção do TCC. O documento salientava que o Curso de Pedagogia da Universidade Federal do Amazonas tem buscado incentivar e fomentar a pesquisa no processo de formação de seus estudantes, sendo de grande importância as parcerias entre as instituições. Assim, a atitude dos profissionais da escola possibilitou a realização de observação direta no espaço da sala de aula da Unidade Prisional Semiaberto Feminino (UPSF). A análise constituída, o contato com o espaço da escola no âmbito da unidade prisional e os registros do diário de campo contribuíram para fundamentar e conhecer melhor o espaço escolar pesquisado, desconstruindo a insegurança que havia diante do ambiente inexplorado, possibilitando troca de experiência e conhecimento da prática docente em relação a teoria e normativos estudados.

A segunda pesquisa centra-se no estudo de políticas linguísticas que envolvem o letramento e o ensino de Língua Portuguesa no contexto prisional amazonense. Assim sendo, 
investigaremos o Plano Estadual de Educação do Amazonas (PEEP) de 2012 e o Projeto "Encontro com a Leitura - Ler Liberta", concebidos, no estudo, como documentos centrais que explicitam ações de políticas linguísticas. Além disso, a escolha dos documentos vinculase ao seu teor que explicitam a organização da oferta de ensino de Língua Portuguesa e do cenário de remição de pena por meio de práticas de letramento como a leitura e a escrita.

Nesse caso, a escolha surgiu por conta da necessidade de se verificar o trabalho que é feito para a condução da leitura, bem como da escrita a partir de políticas educacionais aos jovens e adultos em situação de privação de liberdade. Existem vários encaminhamentos legais que têm sido discutidos e implementados, no intuito de fortalecer uma política de âmbito nacional que assegure o direito à educação, previsto na Lei de Execuções Penais (Lei 7210/84). Em se tratando da leitura, é um instrumento de libertação, quando conscientiza o ser humano, quando o coloca diante da sociedade, refletindo sobre a mesma, dentro de um contexto social e humanitário. Pensando assim, algumas questões ganharam um olhar mais atento, cuidadoso, quanto ao incentivo à leitura ser considerado um dos caminhos para a ressocialização do apenado, a reinserção enquanto cidadão, com vontade e anseios de mudar sua realidade.

No intuito de melhor conduzir as reflexões, o segundo estudo apresenta tópicos, iniciando com a abordagem teórica a respeito de Políticas Linguísticas, sob a luz de Calvet (2007), Orlandi (2007) e Oliveira (2003). Para na sequência, apresentar uma reflexão acerca da Educação no sistema prisional brasileiro, considerando três questões indissociáveis: políticas educacionais, linguísticas e prisionais. Para isso, se teve como base a Constituição Federal/ 1988 e a Lei de Execução Penal n 7.210/1984, nas quais se contextualizam o cenário e a problematização. Destaca-se ainda o ensino de Língua Portuguesa no contexto prisional do Amazonas, no que se refere à aplicabilidade da Legislação Federal e ao Plano Estadual de Educação nas Prisões. Por conseguinte, aborda-se o Provimento n 272 CCJ/AM, que institui a remição de pena pela leitura no Amazonas, para compreender sua efetividade enquanto política linguística atrelada a práticas de letramento.

As duas pesquisas se apresentam marcadamente como qualitativas, uma vez que essa abordagem segundo Chizzotti (2006), provoca "uma partilha densa com pessoas, fatos e locais que constituem objetos de pesquisa, para extrair desse convívio os significados visíveis e latentes que somente são perceptíveis a uma atenção sensível” (p. 26). Assim, os dois estudos partem da análise de documentos e se sustentam em distintos percursos formativos, em que o interesse comum é a oferta educativa no sistema prisional. De modo complementar, 
os estudos partem de um aparato legal que se refere às políticas públicas para a educação de sujeitos privados de liberdade, com peculiaridades da prática docente em uma UPSF e no processo de remição de pena a partir de um projeto de leitura no sistema prisional do Amazonas.

\title{
Os fundamentos legais que consolidam a oferta educativa no sistema prisional
}

Cabe suscitar que a educação é concebida no discurso do direito como uma assistência fundamental que deve ser assegurada a todo o corpo social. Assim, a Constituição Federal, em consonância com documentos, leis e tratados internacionais, tem a educação como um dever do Estado e um direito de todos. Para isso, nos seus artigos 205 e 206 a CF prevê que:

\begin{abstract}
A educação, direito de todos e dever do Estado e da família, será promovida e incentivada com a colaboração da sociedade, visando ao pleno desenvolvimento da pessoa, seu preparo para o exercício da cidadania e sua qualificação para o trabalho. (BRASIL, 1988).
\end{abstract}

Em conformidade com a CF, a Lei de Execução Penal (LEP) - nº 7.210/1984 postula que independentemente de estar privado de liberdade, a garantia educacional deve ser assegurada ao apenado. Portanto, é dever do Estado propiciar o acesso ao ensino de sua população carcerária, sem discriminação, bem como atender às especificidades dos seus educandos, observando os diversos contextos sociais em que eles estão inseridos. A LEP prevê ainda que a assistência educacional compreenderá a instrução escolar e a formação profissional do preso, devendo o Ensino Fundamental ser obrigatório. O objetivo desse direito básico tem como pressuposto prevenir o crime e orientar o retorno à convivência em sociedade.

Art. 17. A assistência educacional compreenderá a instrução escolar e a formação profissional do preso e do internado.

Art. 18. O ensino de primeiro grau será obrigatório, integrando-se no sistema escolar da unidade federativa.

Art. 19. O ensino profissional será ministrado em nível de iniciação ou de aperfeiçoamento técnico.

Parágrafo único. A mulher condenada terá ensino profissional adequado à sua condição.

Art. 20. As atividades educacionais podem ser objeto de convênio com entidades públicas ou particulares, que instalem escolas ou ofereçam cursos especializados. (BRASIL, 1984).

A história da educação brasileira, de modo geral, é marcada por lutas. Contudo, a luta pela institucionalização da educação em estabelecimentos prisionais é recente e pouco efetiva. 
Nessa perspectiva, podemos aventar que uma formalização do ensino nas prisões foi intensificada somente após a LEP $n^{\circ} 7.210 / 84$, ainda que no Amazonas a oferta da educação nas prisões do Estado tenha iniciado no Século XX, com a criação da Escola Agnello Bittencourt, através do Decreto de Número 173, de 12 de maio de 1928, sendo publicado no Diário Oficial, Ano XXXV, Número 9.925, em 13 de maio de 1928 (PEEP-AM, 2015).

O direito à educação no sistema prisional no Brasil é parte das ações da modalidade da Educação de Jovens e Adultos (EJA), por sua vez se associa a educação carcerária prevista nos normativos internacionais e nacionais para a garantia à escolarização dos adultos privados de liberdade. A modalidade de ensino está preconizada em documentos legais da EJA, com particularidade à educação de adultos privados de liberdade previstas no Parecer CNE/CEB $\mathrm{n}^{\circ}$ 4/2010 e na Resolução CNE/CEB n 2/2010. Um dos pontos iniciais para a escolarização de adultos privados de liberdade é a eliminação do analfabetismo, efetivada pela UNESCO e seguida por seus membros subscritores. O Brasil amparou e inseriu o intuito da eliminação do analfabetismo na LDBEN 9394/96 e por meio da Emenda Constitucional no 59, de 2009, na Constituição Federal de 1988. No campo educativo mais recente, reportamos Plano Nacional de Educação (LEI No 13.005/2014) com seus preceitos e intuitos, salientando a meta de $\mathrm{n}^{\circ} 9$, na estratégia 9.8 , que propõe:

[...] assegurar a oferta de educação de jovens e adultos, nas etapas de ensino fundamental e médio, às pessoas privadas de liberdade em todos os estabelecimentos penais, assegurando-se formação específica dos professores e das professoras e implementação de diretrizes nacionais em regime de colaboração estratégia que discorre sobre a educação no sistema prisional. (PNE,2014)

A análise da legislação supõe um esforço recente de sincronizar e incluir a oferta educativa aos jovens e adultos privados de liberdade. Mas um fato importante é que a Lei 9.394/96, que institui as diretrizes e bases da educação no país, silencia a educação prisional. Com efeito, não menciona formalmente na letra da lei determinações para a oferta educativa aos jovens e adultos privados de liberdade. Mesmo assim, ao considerar que a educação é um direito de todos, impõe necessariamente, que todas as instituições, que privam parcialmente ou integralmente a liberdade, devem ser orientadas pela legislação vigente. No Brasil, não é somente a penitenciária que encarcera para fins correcionais, mas a casa do albergado, o hospital de custódia os centros de recuperação, entre outros. Contudo, é perceptível que essas instituições necessitam de um vínculo com a esfera educacional/escolar, para que possa 
atender adequadamente às particularidades das instituições, bem como desenvolver a autonomia de pensamento e a reflexão crítica dos privados de liberdade.

Efetivamente, a LDBEN 9394/96 é um dos documentos mais importantes, depois da Constituição Federal de 1988, no tocante à conjuntura educacional brasileira, já que faz menção, em suas cláusulas, às características de uma educação convencional para confirmar a instrução no ensino regular do aluno, do docente e dos demais profissionais presentes na formação do educando. Assim, a lei dispõe mediante a seus preceitos garantir a particularidade de ofertar a qualquer sujeito a educação. As concepções legais que a LDB expõe são usadas para assegurar a educação para indivíduos privados de liberdade, mas eventualmente, responsabilizando o gestor público pela oferta, acesso e permanência do jovens e adultos no âmbito educacional.

No Amazonas, a análise destaca a Constituição do Estado fundamentada pela Constituição Federal/88, ainda que o acesso e continuidade à Educação Básica sejam declarados nos documentos oficiais, não há citação precisa em relação à educação no sistema prisional. Porém, na Constituição do Estado, no sétimo capítulo, na primeira seção, nos artigos 198 e 199, o Estado tem permissão para assegurar e promover educação ao sistema prisional, pois, nos artigos são estabelecidos direitos ao ingresso de qualquer sujeito em instituições de ensino, os direitos dispostos nos artigos citados, são:

ART. 198. A educação, baseada nos princípios da democracia, da liberdade de expressão, da sabedoria nacional e do respeito aos direitos humanos, é direito de todos e dever do Estado e da família.

Parágrafo único. Como agente do desenvolvimento, a educação será promovida e incentivada com a colaboração da sociedade, visando ao pleno desenvolvimento da pessoa para a elaboração e reflexão crítica da realidade, a preparação para o trabalho e para o exercício da cidadania.

ART. 199. O Sistema Estadual de Educação, integrado por Órgãos e estabelecimentos de ensino estaduais e municipais e por escolas particulares, observará, além dos princípios e garantias previstos na Constituição da República, os seguintes preceitos: I - de observância obrigatória por todos os integrantes do Sistema: igualdade de condições para acesso e permanência na escola; liberdade de aprender, ensinar, pesquisar e divulgar o pensamento, a arte e o saber; pluralismo de ideia e de concepções pedagógicas; [...]

Desse modo, a educação é estimulada e promovida com a cooperação da sociedade, pretendendo desenvolver o pensamento crítico da circunstância atual, disposição para o trabalho e para o exercício dos direitos civis, políticos e sociais. Em suma, os princípios que fundamentam a Constituição do Estado no que diz respeito ao direito à educação no estado do Amazonas, também somam ações e objetivos que servem como base geral para sustentar as 
ações educacionais desenvolvidas a favor dos jovens e adultos privado de liberdade. Ao apenado, por violar as leis e ferir o direito de outros, lhe é conferido pelas leis, o respeito aos direitos humanos e a igualdade de condições, ou seja, a ação educativa no sistema prisional é parte desse direito.

Ainda no âmbito estadual, no que diz respeito à oferta de ensino aos jovens e adultos privados de liberdade, o Amazonas, em 2012, expôs ao Ministério da Educação (MEC) e ao DEPEN, o Plano Estadual de Educação nas Prisões (PEEP). Representantes dos órgãos unidos à segurança pública e a educação do Estado, elaboraram o PEEP em parceria, tendo como intuito ajustar as ofertas do Plano Nacional de Educação nas prisões para a particularidade da região norte.

Em virtude de averiguações “desiguais", apontadas pelo MEC no documento redigido no final de 2014, a sugestão sofreu correções e aguarda homologação definitiva do órgão federal. Dada esta justificativa, o Plano Estadual de Educação nas Prisões não estava vigendo até 2017 no Amazonas. Porém, como o Plano Estadual de Educação nas Prisões está num período de reconstrução, as atividades efetivas nas salas de aulas nas penitenciárias prosseguem os mesmos modelos de Educação de Jovens e Adultos (EJA) praticados nas escolas ditas regulares.

O PEEP/AM é apresentado como um documento que se baseia nos preceitos morais e sociais da "liberdade, na justiça social, na pluralidade, na solidariedade", na restituição técnica e familiar, nas extensões social e individual de sujeitos cientes de seus deveres e direitos, comprometido com sua mudança social. O modo da organização educacional do PEEP/AM, de acordo com LDB 9394/96, flexibiliza as práticas e os métodos, considerando a carga horária, a avaliação e ação articulada ou não com a educação profissional, com projetos de atendimento à educação no âmbito prisional.

A ideia do fortalecimento e sincronização normativa das políticas, para a oferta educativa aos jovens e adultos privados de liberdade, resultou na organização de um quadro que demonstra os direitos assegurados na Legislação nacional e local a partir dos dados gerais das duas pesquisas e do registro específico do primeiro estudo em relação a Unidade Prisional Semiaberto Feminino (UPSF). 


\begin{tabular}{|c|c|c|c|c|}
\hline LEIS & Direito Previsto & PNE & PEE-AM & $\begin{array}{c}\text { Plano de aula da } \\
\text { UPSF }\end{array}$ \\
\hline 章 & $\begin{array}{l}\text { Art. } 205 . \quad \text { A } \\
\text { educação, } \\
\text { direito de todos e } \\
\text { dever do Estado e } \\
\text { da família, será } \\
\text { promovida ra } \\
\text { incentivada com a } \\
\text { colaboração da } \\
\text { sociedade, visando } \\
\text { ao pleno } \\
\text { desenvolvimento da } \\
\text { pessoa, seu preparo } \\
\text { para o exercício da } \\
\text { cidadania e sua } \\
\text { qualificação para o } \\
\text { trabalho }\end{array}$ & $\begin{array}{l}\text { Art. } 2^{\circ} \text { São diretrizes do } \\
\text { PNE: } \\
\text { I - erradicação do } \\
\text { analfabetismo; } \\
\text { II - universalização do } \\
\text { atendimento escolar; } \\
\text { III - superação das } \\
\text { desigualdades } \\
\text { educacionais, com } \\
\text { ênfase na promoção da } \\
\text { cidadania e na } \\
\text { erradicação de todas as } \\
\text { formas de } \\
\text { discriminação; }\end{array}$ & 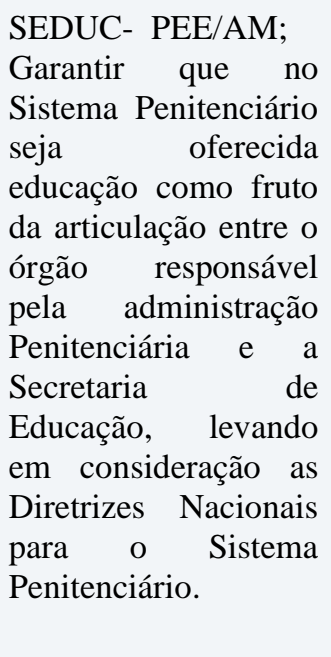 & $\begin{array}{l}\text { Componente } \\
\text { Curricular: } \\
\text { Humanas } \\
\text { Disciplina: } \\
\text { portuguesa } \\
\text { Tema Língua } \\
\text { Reconhecer os limites } \\
\text { dos privados de } \\
\text { liberdade, leitura e } \\
\text { interpretação de textos } \\
\text { Objetivo: identificar os } \\
\text { gêneros textuais } \\
\text { propostos. }\end{array}$ \\
\hline 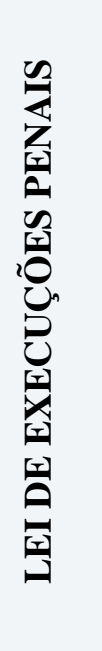 & $\begin{array}{ll}\text { Art.17. } & \text { A } \\
\text { assistência } & \\
\text { educacional } & \\
\text { compreenderá } & \text { a } \\
\text { instrução escolar e a } \\
\text { formação } & \\
\text { profissional } & \text { do } \\
\text { preso e } & \text { do } \\
\text { internado. } & \end{array}$ & $\begin{array}{l}\text { Estratégias: } \\
\text { 9.8) assegurar a oferta } \\
\text { de educação de jovens } \\
\text { e adultos, nas etapas de } \\
\text { ensino fundamental e } \\
\text { médio, às pessoas } \\
\text { privadas de liberdade } \\
\text { em todos os } \\
\text { estabelecimentos } \\
\text { penais, assegurando-se } \\
\text { formação específica } \\
\text { dos professores e das } \\
\text { professoras e } \\
\text { implementação de } \\
\text { diretrizes nacionais em } \\
\text { regime de colaboração; }\end{array}$ & $\begin{array}{l}\text { Implementar } \text { em } \\
\text { Unidades Prisionais e } \\
\text { nos estabelecimentos } \\
\text { que atendam } \\
\text { adolescentes e jovens } \\
\text { infratores, programas } \\
\text { de Educação de } \\
\text { Jovens e } \\
\text { oferecendo } r \\
\text { Alfabetização, Ensino } \\
\text { Fundamental, Ensino } \\
\text { Médio e outras } \\
\text { formas de ofertas, } \\
\text { garantindo raça para o } \\
\text { formação para } \\
\text { mundo do trabalho; }\end{array}$ & $\begin{array}{l}\text { Componente } \\
\text { Curricular: Linguagem. } \\
\text { Disciplina: Artes } \\
\text { Quando a arte e a } \\
\text { história se encontram: } \\
\text { fios e linhas; colagem } \\
\text { em M.D.F } \\
\text { Objetivo: incentivar as } \\
\text { reeducandas para o } \\
\text { desenvolvimento e } \\
\text { trabalhos manuais, } \\
\text { como forma de } \\
\text { reintegração } \\
\text { sociedade. à }\end{array}$ \\
\hline 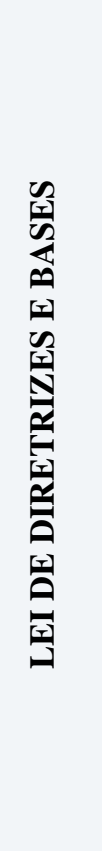 & $\begin{array}{l}\text { Art. } 2^{\circ} \text { A educação, } \\
\text { dever da família e } \\
\text { do Estado, inspirada } \\
\text { nos princípios de } \\
\text { liberdade e nos } \\
\text { ideais } \\
\text { solidariedade } \\
\text { humana, tem por } \\
\text { finalidade o pleno } \\
\text { desenvolvimento do } \\
\text { educando, reu } \\
\text { preparo para o } \\
\text { exercício r da } \\
\text { cidadania e sua } \\
\text { qualificação para o } \\
\text { trabalho. }\end{array}$ & $\begin{array}{l}\text { Meta 9: elevar a taxa de } \\
\text { alfabetização da } \\
\text { população com } 15 \\
\text { (quinze) anos ou mais } \\
\text { para } 93,5 \% \text { (noventa e } \\
\text { três inteiros e cinco } \\
\text { décimos por } \\
\text { cento) até } 2015 \text { e, até o } \\
\text { final da vigência deste } \\
\text { PNE, erradicar or or } \\
\text { analfabetismo absoluto } \\
\text { e reduzir em } 50 \% \\
\text { (cinquenta por cento) a } \\
\text { taxa de analfabetismo } \\
\text { funcional. Estratégias: } \\
9.1 \text { ) assegurar a oferta } \\
\text { gratuita da educação de } \\
\text { jovens e adultos a todos } \\
\text { os que não tiveram } \\
\text { acesso à educação } \\
\text { básica na idade própria; }\end{array}$ & $\begin{array}{lr}\text { Garantir a oferta, o } \\
\text { acesso } & \text { e } \\
\text { permanência } & \text { com } \\
\text { qualidade r } & \text { da } \\
\text { educação para jovens, } \\
\text { adultos e idosos com } \\
\text { distorção idade-série, } \\
\text { ampliando r as } \\
\text { perspectivas } \\
\text { trabalho, renda e de } \\
\text { participação político- } \\
\text { social, (...), em toda } \\
\text { rede de ensino, } \\
\text { inclusive no sistema } \\
\text { prisional; }\end{array}$ & $\begin{array}{l}\text { Componente } \\
\text { Curricular: Ciências } \\
\text { Humanas } \\
\text { Disciplina: Geografia } \\
\text { A estrutura política do } \\
\text { Brasil } \\
\text { Objetivo: reconhecer a } \\
\text { estrutura política do } \\
\text { Brasil, Identificar o } \\
\text { Brasil como uma } \\
\text { potência regional, } \\
\text { Identificar o Brasil no } \\
\text { cenário internacional. }\end{array}$ \\
\hline
\end{tabular}




\begin{tabular}{|c|c|c|c|c|}
\hline LEIS & Direito Previsto & PNE & PEE-AM & $\begin{array}{c}\text { Plano de aula da } \\
\text { UPSF }\end{array}$ \\
\hline 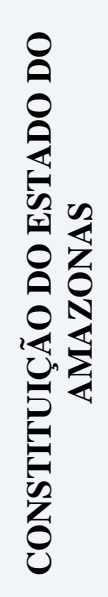 & $\begin{array}{l}\text { ART. 199. O } \\
\text { Sistema Estadual de } \\
\text { Educação, integrado } \\
\text { por Órgãos e } \\
\text { estabelecimentos de } \\
\text { ensino estaduais e } \\
\text { municipais e por } \\
\text { escolas particulares, } \\
\text { observará, além dos } \\
\text { princípios e } \\
\text { garantias previstos } \\
\text { na Constituição da } \\
\text { República. }\end{array}$ & $\begin{array}{l}\text { Art. 8o Os Estados, o } \\
\text { Distrito Federal e os } \\
\text { Municípios deverão } \\
\text { elaborar seus } \\
\text { correspondentes planos } \\
\text { de educação, ou } \\
\text { adequar os planos já } \\
\text { aprovados em lei, em } \\
\text { consonância com as } \\
\text { diretrizes, metas e } \\
\text { estratégias previstas } \\
\text { neste PNE, no prazo de } \\
1 \text { (um) ano contado da } \\
\text { publicação desta Lei. }\end{array}$ & $\begin{array}{l}\text { Coordenar o processo } \\
\text { de implementação, } \\
\text { execução, } \\
\text { manutenção } \\
\text { avaliação das } \\
\text { políticas públicas } \\
\text { para a educação no } \\
\text { Estado, nos diversos } \\
\text { níveis e modalidades } \\
\text { de ensino, observando } \\
\text { as Diretrizes } \\
\text { Nacionais e Estaduais } \\
\text { para jovens e adultos } \\
\text { em situação de } \\
\text { privacão de liberdade }\end{array}$ & $\begin{array}{l}\text { Componente } \\
\text { Curricular: Ciências } \\
\text { Humanas } \\
\text { Disciplina: História } \\
\text { As origens dos estados } \\
\text { brasileiros } \\
\text { Objetivo: Conhecer } \\
\text { através da pesquisa a } \\
\text { origem do estado } \\
\text { brasileiro; Conhecer o } \\
\text { desenvolvimento do } \\
\text { governo português no } \\
\text { Brasil. }\end{array}$ \\
\hline
\end{tabular}

\section{A pesquisa em uma Unidade Prisional Semiaberto Feminina em Manaus}

Os resultados da análise que se apresentam correspondem aos registros do diário de pesquisa usado como parte das observações diretas no campo de pesquisa, método esse utilizado para transcrição do que se foi observado para um estudo interpretativo das ações acompanhadas, portanto é:

[...] um documento pessoal-profissional no qual o estudante [profissional] fundamenta o conhecimento teórico-prático, relacionando com a realidade vivenciada no cotidiano profissional, através do relato de suas experiências e sua participação na vida social (LEWGOY; SCAVONI. 2002.p.63)

$\mathrm{Na}$ construção desta pesquisa, houve a chance de manter contato com os profissionais da escola que atuam no sistema prisional em vários momentos, oportunizando um diálogo fora e dentro do contexto da unidade onde ocorreu a observação.

O contato com alguns profissionais antes das observações na escola, colaborou para desconstruir o medo da realidade escolar, pois de início presumia-se certa agressividade por parte dos jovens e adultos privados de liberdade, e contrariedade por parte dos funcionários que atuam na unidade prisional. De fato, a estudante e a docente, do Curso de Pedagogia assumiam papel de intrusas ao observar o trabalho, mas foram apenas concepções préestabelecidas, que salientam o olhar da insegurança motivada pelas notícias locais e pelo atual contexto violento no cenário nacional.

A necessidade de compreender a sala de aula como campo da prática pedagógica dos professores no sistema prisional, norteou o entendimento da primeira pesquisa e das 
concepções sobre o trabalho docente na educação de jovens e adultos. Na intenção de ampliar a compreensão e melhor agir optou-se em realizar observação direta no espaço escolar da Unidade Prisional Semiaberto Feminina, como metodologia para descrever as ações observadas de modo que se atentou para a estrutura escolar, funcionamento e a própria prática pedagógica do professor em relação à sala de aula.

A escola que serviu como campo de pesquisa funciona na Unidade Prisional Semiaberto Feminina, localizada no bairro da Cachoeirinha, na zona urbana do município de Manaus- Am. Espaço que passou a integrar o sistema penitenciário em 2014, onde antigamente funcionava a Casa do Albergado.

Não ampliamos a necessidade de apresentação do espaço físico da escola, pois a mesma não se encontra num espaço físico regular. $\mathrm{E}$ posteriormente os primeiros levantamentos da legislação foi identificado o decreto $\mathrm{n}^{\mathbf{0}} 7.626$, de 24 de novembro de 2011 . Ao abordar esse decreto de maneira e em espaço distinto da legislação já apresentada, há o reconhecimento de que o campo da legislação sobre o tema é difuso e se encontra em organização em pesquisas que estão em andamento no interior da UFAM. Desse modo, o Decreto Institui o Plano Estratégico de Educação no âmbito do Sistema Prisional, define diretrizes para

[...] III - contribuir para a universalização da alfabetização e para a ampliação da oferta da educação no sistema prisional;

fortalecer a integração da educação profissional e tecnológica com a educação de jovens e adultos no sistema prisional;

promover a formação e capacitação dos profissionais envolvidos na implementação do ensino nos estabelecimentos penais; e

viabilizar as condições para a continuidade dos estudos dos egressos do sistema prisional.

Parágrafo único. Para o alcance dos objetivos previstos neste artigo serão adotadas as providências necessárias para assegurar os espaços físicos adequados às atividades educacionais, culturais e de formação profissional, e sua integração às demais atividades dos estabelecimentos penais. (BRASIL, 2011)

De acordo com o parágrafo único descrito, é necessário acomodar-se nos espaços físicos para que seja assegurado o direito às práticas pedagógicas. Visto que, na instituição prisional há espaço para adequar as atividades educacionais podemos declarar que ali atua uma escola

A escola, visto ser apontada como local de comunicação, de interações pessoais, onde o aprisionado pode se mostrar sem máscaras, afigura-se, portanto, como oportunidade de socialização, na medida em que oferece ao aluno outras possibilidades referenciais de construção da sua identidade e de resgate da cidadania perdida. (ONOFRE, 2007, P.15) 
Em relação às observações diretas, a pesquisa será descrita a partir de dois segmentos básicos, como se apresenta os aspectos físicos da sala de aula aos estudantes privados de liberdade e como é a atuação docente no âmbito prisional, considerando o espaço físico da UPSF e o funcionamento escolar. Nos vários momentos que se sucederam as observações diretas, a estrutura física educacional estava a funcionar, sala refrigerada e iluminada, carteiras, armários e quadro branco em bom estado de preservação.

A observação direta na UPSF foi uma maneira de aproximação ao campo pesquisado, subsidiando as concepções teóricas e previsões normativas sobre a oferta educativa no sistema prisional. O contato com a escola permitiu uma análise da realidade com esclarecimentos sobre a relação de ensino/aprendizagem e dos desafios da prática docente no espaço prisional.

A conjuntura da classe trabalhadora na área da educação não é uma das mais valorizadas, diversos aspectos expõem a desvalorização do trabalho docente, como: sobrecarga de trabalho, salários irrisórios, investimentos limitados para material didático, falta de infraestrutura. Assim, logo percebemos que as condições de trabalho não atendem diversas particularidades da educação regular, menos ainda na educação de sujeitos privados de liberdade.

Diante dos aspectos já citados, o professor da educação escolar no sistema prisional enfrenta uma realidade mais árdua, pois ao entrar no ambiente de trabalho encontra com um espaço escolar (sala de aula) distinto daquele visto no espaço-físico dito regular. Inicialmente todos passam pelo procedimento de inspeção ${ }^{3}$. Em seguida, pela presença constante dos agentes penitenciários, em um universo vulnerável a confusão e possibilidades concretas de motim, tendo o trabalho cercado pela rotineira ação de guardas armados acompanhando o processo educativo, no exterior da sala de aula ${ }^{4}$, porém essa tensão acaba interferindo na dinâmica necessária ao funcionamento de uma sala de aula e em seu ambiente de trabalho.

Em virtude ao ambiente de trabalho, o professor precisa ter a noção que está propício a situações periculosas, pois o estudante por ele atendido faz parte de um grupo em conflitos com a lei. Assim, evidenciamos um caso em especial, ocorrido durante as semanas de observações diretas, que permitiu acompanhar os reflexos resultantes da tentativa de fuga de algumas detentas no funcionamento da sala de aula. Em relação a isso, foi possível ouvir em sala de aula relatos de algumas estudantes que foram impedidas de participar das aulas no dia posterior a tentativa de fuga ocorrida em um fim de semana. Torna-se importante lembrar que,

\footnotetext{
${ }^{3}$ Os professores exigem as revistas, pois desejam ser insuspeitos para continuar a oferta ininterrupta das aulas.

${ }^{4}$ Há um aparente respeito por determinados espaços no presidio, a capela, a enfermaria e a sala de aula emanam essa sensação.
} 
os procedimentos de segurança são fundamentais para a compreensão de que o trabalho no sistema prisional é de extrema inquietação e divergência social.

Conforme informações constantes no endereço eletrônico da SEDUC (2016), os professores que trabalham nas salas de aula das Escolas Estaduais Giovanni Figliuolo, nos presídios do Município de Manaus são contratados por Processo Seletivo Simplificado (PSS), em regime temporário com legitimidade de 24 meses, possibilitando ou não ser estendido. A SEDUC, ao promover o Processo Seletivo Simplificado (PSS), apresenta em seu edital a carga horária máxima de 40 horas semanais.

$\mathrm{Na}$ observação direta da UPSF, registrou-se a dificuldade da docente em atuar nas horas previstas para as aulas. A proposta curricular adotada pela Escola Estadual Giovanni Figliuolo na UPSF é a Educação de Jovens e Adultos, com duas turmas, uma no turno matutino e outra no vespertino. As aulas na UPSF acontecem num curto tempo: de segundafeira à quinta-feira, com a durabilidade de 2 horas diárias nos respectivos turnos. Em momentos de situação atípica do regime interno da Unidade Prisional, a duração da aula é apenas de 1 hora. Destaca-se que nas sextas-feiras não são ministradas as aulas na UPSF, pois neste dia a professora se reúne com os docentes das diferentes unidades prisionais para desenvolver o planejamento e elaborar estratégias de aula ou tratar questões relacionadas ao trabalho pedagógico e escolar.

Observou-se que a carga horária do plano de ensino é programada para 4 horas diárias para cada turno, constando que as aulas pela manhã começam $8 \mathrm{~h} 30 \mathrm{~min}$ às $12 \mathrm{~h} 30 \mathrm{~min}$ e pela tarde 13h30min ás 17h30min. Todavia, há uma divergência entre o plano de aula elaborado e disponibilizado pela professora, em relação ao tempo lecionado na sala de aula, isso se dá por alguns fatores internos da UPSF, dentre eles: a conduta em relação à educação por parte de alguns apenados e o regimento interno do mecanismo de segurança da instituição e o penal.

Dessa forma, a atuação docente comporta alterações constantes que implicam no resgate do sujeito privado de liberdade, uma vez que envolve o desempenho do estudante. Consequentemente, prejudicando a prática docente e a reinserção educativa ${ }^{5}$ do estudante em relação ao ensino aprendizagem.

A existência de uma cultura própria da prisão torna a escola um espaço singular, e o seu cotidiano nem sempre permite apreender os significados vividos naquele espaço-tempo. O desafio posto é como se inserir nesse mundo, sem abdicar de seus elementos culturais próprios, sem perder fios da trama que revela a sua essência. (ONOFRE; JULIÃO, 2013, p.63)

\footnotetext{
${ }^{5}$ Termo cunhado especificamente para essa pesquisa, pois resulta da percepção que motivar o estudante, nas condições descritas, será o principal contributo da oferta educativa.
} 
Nesse sentido, compreender o contexto de atuação docente no espaço prisional levanos a refletir que a sala de aula é o espaço disponibilizado para que o docente tenha a oportunidade de desenvolver suas habilidades, bem como mediar os processos educativos para que haja uma troca de saberes e os estudantes recomecem um processo que abandonaram e que estatisticamente se relaciona com sua condição no presidio.

Após as informações de como era o contexto que os professores vivenciam, os pensamentos iniciais sobre o espaço escolar marginalizado e desumano foram se modificando, pois como afirma Candau (1998)

A maior dificuldade está no fato de nós mesmos, educadores, não termos sido educados para os Direitos Humanos. O primeiro passo, então, seria o da auto-educação, para irmãos desvendando e ultrapassando o nosso egocentrismo, autoritarismo, rigidez, já que fomos socializados num sistema de repressão e de concorrência, e dele somos vítimas. (CANDAU, 1998, p.41)

Conforme a observação realizada, a Unidade Prisional Semiaberto Feminino apresenta um número razoável de alunas matriculadas, porém, a cada semana o quantitativo de matriculadas modifica-se, pois é uma unidade de sistema rotativo que recebe internas com progressão de regime penal transição essa assegurada pela lei $\mathrm{n}^{\mathbf{0}}$ 7.210/84 (LEP), caracterizando a oferta educativa de maneira ainda mais distinta. Com este sistema rotativo foi possível deduzir o quão desafiador é a prática do docente, logo compreendendo o relato da professora "O maior desafio é ter alunas até o fim do ano letivo, pois essa é uma penitenciária rotativa e isso atrapalha o trabalho com elas... " [Registro do diário de campo].

A proposta curricular do anexo escolar corresponde ao segundo segmento do Ensino Fundamental da EJA que se refere à etapa de $6^{\circ}$ ao $9^{\circ}$ ano, assim preconizando um modelo pedagógico favorável que proporcione a Educação Básica, desse modo restabelecendo um espaço para a formação e para a remição de pena. As aulas do segundo segmento na UPSF são ministradas por uma professora formada em Pedagogia, que leciona todas as disciplinas proposta pelo currículo previsto para o período e ano escolar,

A prática docente na EJA é complicada para estudantes de escolas na rede de ensino, mas a EJA para jovens e adultos privados de liberdade é ainda mais desafiadora, em que se destacam desafios e particulares, até mesmo por conta das barreiras impostas pelo ambiente, que muitas vezes limitam a prática do professor em sala de aula. Mesmo com os limites que configuram a educação no âmbito prisional, é preciso salientar que a turma é bem participativa tanto nas atividades escritas quanto nas atividades manuais. 
A partir da leitura visual dos planos de aula, nota-se que a prática docente na UPSF se constitui em uma ordem-teórica bem básica, não por falta de experiência da professora, porém, professora, mas porque, o tempo de aula é curto, e há a proibição das estudantes levarem materiais para a cela e também por falta de investimento do Estado em materiais didáticos. Esse cenário acaba por reforçar ou condicionar o uso de práticas tradicionais, pois é a maneira mais simples para transmitir o conteúdo. A falta de investimento nas políticas educacionais no sistema prisional não foi objeto dessa análise, ainda que interfira diretamente na prática docente, pois é um assunto de igual complexidade, que no caso do Amazonas envolve até o processo de terceirização no sistema prisional.

Os planos de aula resultam em propostas voltadas à EJA, porém com objetivos específicos que vão além dos componentes curriculares tradicionais, incluindo estratégias de educação reflexiva que incentive um ensino aprendizagem de maneira significativa, sendo assim, introduzindo múltiplos temas que propiciem aos estudantes idealizarem alternativas para a área profissional. Logo, o Parecer CNE/CEB nº 4/2010, aprovado em 9 de março de 2010 - Resolução CNE/CEB nº 2, de 19 de maio de 2010 esclarece:

A escola seja para criança, jovens e adultos, inclusive em ambientes de privação de liberdade, nesta concepção, deve ser concebida como um espaço de encontro e socialização ao mundo livre em que o saber é apenas um dos elementos para a sua constituição. É preciso romper com a concepção tradicional e reducionista de escola, cujo objetivo central está na aquisição de conteúdos pragmáticos e muitas vezes descontextualizados do ambiente em que se vive, principalmente do mundo moderno. (MEC/SECAD, p.15, 2010)

O êxito das atividades propostas aos educandos, precisa muito mais que comprometimento do professor com suas práticas, uma vez que, pois, necessita da dedicação dos diferentes profissionais envolvidos com o contexto prisional. Desse modo, para que a prática docente seja significativa deve considerar ainda que:

O mundo da prisão é antes de mais nada um mundo complexo. Não há objetivos comuns definidos, exceto o imediatismo de segregar o indivíduo da sociedade. O conflito do preso com os funcionários da prisão e com os demais presos é uma constante. A vida social numa prisão é sobremaneira difícil e quase impossível devido a um ambiente de desconfiança total, esperteza e desonestidade lá reinantes. É um mundo do "eu", "mim" e "meu" antes do "nosso", "deles" e "dele". (OLIVEIRA, 1984, p.64)

Nesse sentido, a oferta educativa dentro do sistema prisional se caracteriza, essencialmente, por ser a porta de entrada, recomeço ou percepção da necessidade de 
retomada na vida escolar do estudante, para que ao sair da penitenciária possa se integrar na escola regular, constituindo-se naquilo que no estudo passamos a denominar de Reinserção Educativa. Assim, a prática docente é um componente motivador para o empoderamento dos jovens e adultos privados liberdade.

Para que haja essa Reinserção Educativa a cooperação para as ações pedagógicas realizadas no sistema prisional devem ser realizadas em conjunto com os demais agentes da unidade, pois, de acordo com o Parecer CNE/CEB n ${ }^{\circ}$ 4/2010, os profissionais comprometidos com a proposta de educação no sistema prisional necessitam considerar que o gerenciamento deva ofertar "gestão, articulação e mobilização; formação e valorização dos profissionais envolvidos na oferta de educação na prisão [...]” (MEC/SECAD p.2, 2010), onde se valorize a política de reinserção social do sujeito privado de liberdade e não sobrecarregue somente o professor como agente transformador do contexto prisional.

\section{Do cenário teórico da política linguística ao ensino de Língua Portuguesa no contexto prisional amazonense}

A segunda proposta de pesquisa parte do enquadramento teórico da política linguística ao ensino da Língua Portuguesa no Amazonas. Quanto ao conceito de Política Linguística, refere-se a um campo teórico que emergiu a partir da década de 1950, com o objetivo de tratar de duas questões indissociáveis: política linguística e planejamento linguístico. O primeiro termo diz respeito às medidas adotadas pelas instituições estatais em relação aos usos da língua; e o segundo trata das ações realizadas para que haja aplicação dessas medidas. "O sintagma language planning, traduzido para o português por planejamento linguístico apareceu em 1959 num trabalho de Einar Hugen (...) o autor procurava mostrar nesse trabalho a intervenção normativa do Estado" (CALVET 2007, p.12). A problemática cunhada por Hugen foi fundamental para delinear uma disciplina que permite um ponto de encontro entre a Sociolinguística e a legislação. Enquanto que o ensino da Língua Portuguesa se compõe pelas ações de políticas linguísticas propostas pelo Estado, que perpassam o ensino, bem como o aprendizado de Língua Portuguesa e se desdobram em torno do provimento $\mathrm{n}^{\circ} 272 \mathrm{CCJ} / \mathrm{AM}$ que institui a remição de pena pela leitura, por meio do projeto de letramento Encontro Com a Leitura - Ler Liberta, que demanda a prática da leitura e da escrita de seus participantes.

A Política Linguística passou por várias modelagens até alcançar o cenário teórico atual. Da década de 1950 até meados de 1970, as pesquisas realizadas na área, trataram, em grande medida, de questões relacionadas ao conceito de planejamento linguístico (intervenção do Estado) sobre a língua. Conforme Calvet (2007), nessa época, o pensamento predominante 
de estudiosos como Hugen, Rubin, Gupta, Jernudd, Fishman, Ferguson etc., era o de que há uma relação subordinativa entre a política linguística e o planejamento linguístico. Essa abordagem foi reformulada nos estudos linguísticos, abandonando dois conceitos: o de planejamento vinculado ao propósito de padronizar, melhorar uma língua, e o de língua como um instrumento de interação.

A popularização do conceito de planejamento, influenciado fortemente por Hugen, foi essencial para consolidar a disciplina. Entretanto, Calvet (2007) pontua que na década de 1960, o planejamento linguístico não abordava a questão do poder que perpassava as relações linguísticas, bem como se limitava a propostas ultrapassadas de uniformização da língua.

Em suma, Calvet (2007, p. 75) pontua que: “A questão primordial levantada pela própria ideia de política linguística é a seguinte: em que medida o homem pode intervir sobre a língua ou sobre as línguas? Inúmeros exemplos nos mostram que essa intervenção é possível, mas eles não dispensam a teorização.” Nessa perspectiva, a política linguística serve para mostrar que entre as propostas e ações do Estado há a predominância do político que regula o que pode circular, o que deve ser silenciado, bem como apagado. É esse político que molda as relações de poder e permite o uso de uma forma da língua em detrimento de outra.

Sobre o político na língua, Orlandi $(2007$, p. 8) assevera que:

Quando falamos de Política Linguística enquanto Política de Línguas, damos à língua um sentido político necessário. Ou seja, não há possibilidade de se ter uma língua que não esteja já afetada desde sempre pelo político. Assim, quando pensamos em política de línguas já pensamos de imediato nas formas sociais sendo significadas por e para sujeitos históricos e simbólicos em suas formas de existência, de experiência, no espaço político de seus sentidos.

Esse conceito abordado por Orlandi aproxima-se do que se propõe, à medida que se passa a conceber a língua como sempre já afetada por relações políticas. Isso significa dizer que as políticas não emanam apenas dos aparelhos de Estado, mas também das microrrelações de poder. Pensar que somente as instituições repressoras têm poder é retroceder teoricamente. Para Oliveira (2003), no início, houve uma limitação no alcance da disciplina, pois tentou-se reduzi-la ao conceito de políticas como as intervenções explícitas do Estado. Por tudo isso, infere-se que nem sempre as maiores intervenções políticas são as explícitas, mas também as implícitas.

Considerando os documentos legais de âmbito nacional abordados anteriormente, cabe-nos questionar de que modo a legislação amazonense aplica a legislação federal em 
relação à educação prisional. Com efeito, examinaremos os dados apontados no Plano Estadual de Educação do Amazonas (PEEP, 2012).

No Amazonas, a Secretaria de Estado de Educação e Qualidade do Ensino - SEDUC é a responsável em oferecer o ensino formal e materializar toda a legislação da federação que trata da educação prisional. Em 2012, a SEDUC, em Parceria com a Secretaria de Estado de Justiça e Direitos Humanos - SEJUS apresentaram o Plano de Educação nas Prisões à Secretaria de Educação Continuada, Alfabetização, Diversidade e Inclusão e ao Departamento Penitenciário Nacional. Com o intuito de obter recursos para qualificar a oferta da educação nos estabelecimentos penais de 2012 a 2014. O PEEP apresenta um espelho quantitativo da oferta, bem como dos atendimentos educacionais realizados no estado.

Como já abordado, a modalidade educacional que atende aos jovens e adultos privados de liberdade é a Educação de Jovens e adultos - EJA. A SEDUC oferta o $1^{\circ}$ e o $2^{\circ}$ segmento do Ensino Fundamental, bem como o Ensino Médio para todos os estabelecimentos prisionais do Estado.

Em relação ao grau de escolaridade dos detentos, conforme o PEEP (2012), há 450 indivíduos que possuem alfabetização; 2413 o Ensino Fundamental incompleto; 980 o Ensino Fundamental anos iniciais; 415 o fundamental anos finais; 834 o ensino fundamental completo; 727 o ensino médio incompleto; 284 o Ensino Médio completo e o ensino superior com apenas 8 .

Consultando o material que constitui o corpus da presente pesquisa, verifica-se que no Amazonas há 18 unidades prisionais, no entanto, apenas 16 oferecem atividades educacionais. No tocante ao Ensino Médio, a oferta está restrita a três municípios: em Manaus, com 163 alunos matriculados, em Tabatinga com 43 e em Itacoatiara com 16 educandos. Nos demais municípios não há oferta de Ensino Médio, isso se justifica pela pouca demanda de estudantes que atendam aos requisitos exigidos.

A realidade educacional dos estudantes privados de liberdade é mais precária do que das demais escolas. No interior do Estado, há a apresentação de um cenário preocupante. De 09 municípios, três estão desassistidos: Maués, Tefé e Itapiranga. Na capital, há somente uma escola para atender aproximadamente 6 mil reclusos. Essa situação, certamente dificulta a remição de pena pelo estudo, prevista na LEP se efetive.

A partir dos dados apresentados no Plano Estadual de Educação nas Prisões em 2012, observa-se que a educação no sistema prisional do Amazonas necessita de no mínimo, dois aspectos: o primeiro deles é em relação ao aumento de oferta de vagas para o Ensino 
Fundamental, principalmente no interior. $\mathrm{O}$ segundo diz respeito à contratação de professores habilitados para o exercício docente em suas áreas de atuação.

No que concerne à formação dos professores que atuam na área de Língua Portuguesa há apenas um professor com formação em Letras, os outros três profissionais que completam o quadro docente são de áreas como Engenharia, Matemática, Geografia. Os dados apresentados no PEEP (2012) mostram que entre formação docente e área de atuação há uma grande distância. Esse fator pode incidir negativamente na condução das aulas de Língua Portuguesa e por conseguinte na remição penal.

\section{O projeto Ler Liberta: um encontro com a literatura e com a prática de letramento}

No que concerne ao surgimento do projeto Ler Liberta, para cumprir o que recomenda o Conselho Nacional de Justiça, em 30 de maio de 2016, foi publicado o provimento $\mathrm{n}^{\mathrm{o}} 272$ CGJ/AM que institui o programa "Encontro com a Leitura - Ler Liberta", assinado pela Corregedoria-Geral de Justiça do Estado do Amazonas. De acordo com o provimento $\mathrm{n}^{\circ} 272$, o programa Ler liberta foi criado "considerando que a atividade da boa leitura redime e liberta motivando o desenvolvimento dos valores transcendentais do ser, além de cumprir com o princípio da dignidade humana" (AMAZONAS, 2016, p.39).

No que tange à participação no projeto, é necessário que apenados manifestem interesse em desenvolver as atividades realizadas no programa e façam uma inscrição na sua unidade prisional.

Em relação às condições materiais, no parágrafo único, do $3^{\circ}$ artigo, o provimento exige que haja, nos acervos das bibliotecas dos presídios, o mínimo necessário de exemplares diferentes das obras a serem trabalhadas no Programa, e que elas atendam às particularidades dos participantes, (AMAZONAS, 2016, p. 40).

As principais exigências, em relação à produção textual, que um apenado deve cumprir para ter sua pena diminuída são: escrever uma resenha ou um resumo de uma obra literária, com originalidade e clareza. Assim, o provimento no 272-CGJ/AM, determina que:

Art. $4^{\circ}$. Segundo o critério objetivo, o reeducando terá o prazo de 21 (vinte e um) a 30 (trinta) dias para a leitura de uma obra literária, apresentando ao final deste período uma resenha ou resumo de próprio punho a respeito do assunto, possibilitando, segundo critério legal e regulamentar de avaliação, a remição de 04 (quatro) dias de sua pena por obra lida e resenhada, e ao final de até 12 (doze) obras lidas e avaliadas, terá a possibilidade de remir até 48 (quarenta e oito) dias no prazo de 12 (doze) meses, observada a capacidade gerencial da Unidade. (AMAZONAS, 2016, p.41). 
É relevante pontuar que, mesmo expressando interesse em participar do projeto, um reeducando do sistema penal amazonense só poderá remir pela leitura se for selecionado pela equipe penitenciária de sua Unidade (AMAZONAS, 2016).

Em relação à avaliação dos textos, a justiça determina que:

a) $\mathrm{Na}$ capital, de comissão específica, com finalidade pedagógica, a ser nomeada pelo Diretor de cada Unidade Prisional e por ele presidida, com atribuição de coordenação de medidas assistenciais de recuperação dos reeducandos.

b) No interior, do Diretor do estabelecimento prisional ou quem lhe faça às vezes. (AMAZONAS, 2016, p. 41-42).

Os profissionais designados para avaliação dos textos devem ser pedagogos, funcionários públicos ou voluntários indicados por Diretor de cada Unidade Prisional. Esses profissionais ficam responsáveis por avaliar alguns itens determinados no provimento $\mathrm{n}^{\circ} 272$ CGJ/AM como:

a) Estética: respeitar parágrafo e margem, não rasurar, e apresentar letra legível;

b) Limitação ao tema: limitar-se a resenhar somente o conteúdo do livro, isto

é, não citar assuntos alheios ao objetivo proposto;

c) Fidedignidade: não aceitar resenhas que sejam consideradas como plágio. (AMAZONAS, 2016, p. 42).

Embasada numa concepção de letramento ideológico, cunhada por Street (2003), que concebe as práticas letradas a partir da sua relação com o contexto sociocultural, Kleiman (2000, p. 238) apresenta o seguinte conceito sobre projetos de letramento:

Representa um conjunto de atividades que se origina de um interesse real na vida dos alunos e cuja realização envolve o uso da escrita, isto é, a leitura de textos, que de fato, circulam na sociedade e a produção de textos que serão lidos, em um trabalho coletivo de alunos e professor, cada um segundo sua capacidade.

Os projetos de letramento configuram-se, portanto, como a união entre teoria e prática, que se manifesta, predominantemente em ambiente pedagógico. Nesse sentido, numa perspectiva didática, um projeto viável de letramento faz parte de um trabalho que relaciona o ensino e a aprendizagem de textos orais ou escritos com as histórias de vida de professores e estudantes.

No caso do projeto Ler Liberta, cabe ressaltar que há uma exigência de domínio da escrita e da leitura por parte da população carcerária, algo que os dados aqui apresentados demonstram ser um problema, uma vez que os apenados têm uma formação educacional precarizada. Desse modo, quanto mais distante da realidade dos sujeitos forem os contextos 
em que a linguagem escrita trabalhada na escola estiver no cotidiano, mais perdidos eles estarão em relação aos letramentos dominantes. Portanto, aqueles que não estiverem inseridos em ambientes de práticas de leitura e escrita formal, em que a língua culta é empregada, terão estas maiores dificuldades em produzir textos nesta modalidade. De acordo com Lillis (2003), é preciso levar em consideração que nos ambientes escolarizados haverá sempre o encontro com vivências diferentes de relações com a escrita que não podem ser negligenciados.

De acordo com o provimento $\mathrm{n}^{\circ} 272$, o programa/projeto Ler liberta foi criado "considerando que a atividade da boa leitura redime e liberta motivando o desenvolvimento dos valores transcendentais do ser, além de cumprir com o princípio da dignidade humana" (AMAZONAS, 2016, grifo nosso). O sintagma boa leitura, chama atenção porque essa exigência enseja em outra: a boa escrita. Nesse sentido, para a questão há a necessidade de se examinar de que maneira essas competências são estimuladas nas prisões e como o ensino de Língua Portuguesa relaciona-se a elas.

Se for considerada a dimensão social da linguagem a partir dessa concepção, percebese que o projeto Ler Liberta, é, antes de tudo, uma proposta que faz repensar novas perspectivas pedagógicas de letramento que melhor atendam às necessidades dos reclusos.

Conforme Kleiman (1995, p. 19), “o letramento é um conjunto de práticas sociais que usam a escrita, enquanto sistema simbólico e enquanto tecnologia, em contextos específicos, para objetivos específicos."

O projeto Ler Liberta é concebido aqui como um projeto de letramento. Nesse sentido, Kleiman (2000, p. 238) assevera que esse tipo de projeto:

Representa um conjunto de atividades que se origina de um interesse real na vida dos alunos e cuja realização envolve o uso da escrita, isto é, a leitura de textos, que, de fato, circulam na sociedade e a produção de textos que serão lidos, em um trabalho coletivo de alunos e professor.

Considerando o cenário de aplicação desse programa/ projeto no Amazonas, o último relatório de informações penitenciárias, o Infopen (2014), não apresentou nenhum matriculado no programa de remição pela leitura. Entretanto, de acordo com informações obtidas na secretaria de educação, em maio de 2016, havia aproximadamente 200 matriculados.

Como já visto anteriormente, a população carcerária do Amazonas é uma população que não teve acesso à educação na idade prevista em lei, e continua não tendo essa assistência na prisão. 
Em suma, o intuito não é criar uma relação causal entre ensino formal e letramento. Mas não se deixa de considerar que o sujeito deve estar imerso num meio sócio-discursivo em que possa ter acesso a diversas práticas de letramento, para interagir socialmente. Nesse sentido, o sujeito privado de liberdade, tona-se marginalizado, à medida que a sua interação textual é interditada pelo cárcere.

\section{Considerações finais}

A discussão e os resultados apresentados, tanto em referência à aproximação com o ambiente escolar na Unidade Prisional Semiaberto Feminino, quanto à Política linguística e sua efetivação na oferta educativa no sistema prisional indicam que, mesmo com o amparo dos documentos normativos, que asseguram o direito dos jovens e adultos privados de liberdade, a educação no nesse espaço desempenha uma função auxiliar, pois seus aspectos legais não se configuram da mesma forma no plano da ação concreta e cotidiana. Neste sentido, as atividades evidenciadas nas duas pesquisas, estão voltadas à Reinserção Educativa dos jovens e adultos privados de liberdade.

Os dois estudos também suscitam a reflexão de que não basta apenas assegurar a oferta de educação no sistema prisional, se não for acompanhada de mecanismos que colaborem para que os profissionais e projetos alcancem os objetivos educacionais previstos. Nesse caso, é preciso considerar a oferta educativa e a prática da leitura como práticas singulares, pois contribuem com a reinserção do estudante à sociedade.

Desse modo, a aproximação do campo de pesquisa proporcionou compreender algumas peculiaridades da prática docente e da efetividade de ações como o Ler Liberta, no sistema prisional. A implementação da possibilidade de remição de penas pela leitura e pela escrita do gênero discursivo resenha marcam essa deriva. Porém, o que se percebe é a presença de um discurso grafocêntrico, que possibilitaria o empoderamento do estudante por meio da escrita.

Mesmo que o cenário constante das pesquisas apresente a oferta educativa, a quantidade de municípios sem local de estudo, a inexistência de bibliotecas e a superlotação ainda são limitadores da possibilidade de Reinserção Educativa dos jovens e adultos. Secundariamente, também observou-se que o simples acesso ao Ensino Fundamental e, substancialmente, ao Ensino Médio e Superior reduzem, drasticamente, a possibilidade de práticas conflituosas com a lei. 


\section{Referências}

AMAZONAS. Provimento ${ }^{\circ}$ 272-CCJ/AM. Manaus: Corregedoria-Geral de Justiça do Estado do Amazonas, 2016.

AMAZONAS. Secretaria de Estado da Educação e Qualidade de Ensino; Secretaria de Justiça e Direitos Humanos. Plano Estadual de Educação nas Prisões. Manaus: AM, 2015.

AMAZONAS. Constituição do Estado do Amazonas. http://www.ale.am.gov.br/wpcontent/uploads/2015/01/Constituicao-do-Estado-do-Amazonas-atualizada-2015.pdf

AMAZONAS. Secretaria de Estado da Educação e Qualidade do Ensino - SEDUC. Plano Estadual de Educação nas Prisões. Manaus. 2012.

BRASIL. Constituição da República Federativa do Brasil de 1988.

http://www.planalto.gov.br/ccivil_03/constituicao/constituicao.htm. Acesso em: 02 dez. 2016.

BRASIL. Lei de Execução Penal $\mathbf{n}^{\mathbf{0}}$ 7210/84. Disponível em: http://www.planalto.gov.br/ccivil_03/leis/L7210.htm. Acesso em: 30 nov. 2016.

BRASIL. Lei de Diretrizes e Bases da Educação no 9394/96. Disponível em: http://www.planalto.gov.br/ccivil_03/leis/L9394.htm. Acesso em: 02 dez. 2016.

BRASIL. Plano Nacional de Educação - PNE. Lei no 13.005/2014. Disponível em: http://www.planalto.gov.br/ccivil_03/_ato2011-2014/2014/lei/113005.htm. Acesso em: 02/06/2016.

BRASIL. Resolução CEB/CNE no 04/2010, que estabelece as Diretrizes Curriculares Nacionais para a Educação de Jovens e Adultos Privados de Liberdade. http://portal.mec.gov.br/expansao-da-rede-federal/323-secretarias-112877938/orgaosvinculados-82187207/12992-diretrizes-para-a-educacao-basica. Acesso em: 02/06/2016.

BRASIL. Resolução CNE/CEB n⿳0 02/2010. Dispõe sobre as Diretrizes Nacionais para a oferta de educação para jovens e adultos em situação de privação de liberdade nos estabelecimentos penais. http://portal.mec.gov.br/expansao-da-rede-federal/323-secretarias112877938/orgaos-vinculados-82187207/12992-diretrizes-para-a-educacao-basica. Acesso em: 02/06/2016.

BRASIL. Decreto n⿳ 7.626/2011. Plano Estratégico de Educação no âmbito do Sistema Prisional - PEESP. http://www.planalto.gov.br/ccivil_03/_ato20112014/2011/decreto/d7626.htm

BRASIL. Ministério da Justiça. Código Penal Brasileiro. Brasília: DF, 1940.

CALVET, Luis-Jean. As políticas linguísticas. São Paulo: Parábola/IPOL, 2007.

CANDAU, Vera Maria et. all. Sou criança, tenho direitos: oficinas pedagógicas de direitos humanos. Petrópolis, RJ: Vozes, 1998. 
CHIZZOTTI, A. Pesquisa qualitativa em ciências humanas e sociais. Petrópolis: Vozes, 2006.

CONSELHO NACIONAL DE JUSTIÇA. Recomendação n ${ }^{\circ 44}$. Disponível em: http://www.cnj.jus.br/busca-atos-adm?documento=1235. Acesso em: 02 dez. 2016.

COSTA, Ana Sheila Fernandes; AKKARI, Abdeljalil; SILVA, Rossana Valéria Souza. Educação básica no Brasil: políticas públicas e qualidade. Revista Práxis Educacional, Vitória da Conquista, v.7, n. 11, jun./dez. 2011. Disponível em: http://periodicos2.uesb.br/index.php/praxis/article/view/666. Acesso em: 14 ago. 2017.

FREIRA, Maria Auxiliadora S. Práxis pedagógica e professores intelectuais: refletindo as tensões e concepções da formação/prática docente. Revista Práxis Educacional, Vitória da Conquista, v.1, n. 1, jan./dez. 2005. Disponível em: http://periodicos2.uesb.br/index.php/praxis/article/view/485. Acesso em: 13 nov. 2017.

KLEIMAN, Angela. Modelos de letramento e as práticas de alfabetização na escola na escola. In: KLEIMAN, Angela B. (Org.) Os significados do letramento: uma nova perspectiva sobre a prática social da escrita. Campinas: Mercado de Letras, 1995.

KLEIMAN, Angela. Oficina de leitura. 8. ed. Campinas: Pontes, 2000.

INFOPEN. Levantamento Nacional de informações penitenciárias - Ano de 2014. Disponível em: http: estaticogl.globo.com/2016/06/23/relatório-do-infopen-junho-2016.pdf. Acesso em: 02 dez. 2016.

LEWGOY, Alzira Ma . B; SCAVONI, Ma Lucia. Supervisão em Serviço Social: a formação do olhar ampliado. In: Revista Texto \& Contextos. EDIPUCRS. Porto Alegre: 2002

LILLIS, T.; SCOTT, M. Defining academic literacies research: issues of epistemology, ideology and strategy. Journal of Applied Linguistics, 4, p.5-32, 2003.

MARÍN, Jorge Garcia. Educación y reproducción cultural: el legado de Bourdieu. Revista Práxis Educacional, Vitória da Conquista, v. 2, n. 2, jan./dez. 2006. Disponível em: https://periodicos2.uesb.br/index.php/praxis/article/view/513. Acesso em: 12 mar. 2017.

ONOFRE, Eunice M. C. Educação escolar entre as grades. São Paulo: Edufscar, 2007.

ONOFRE, Elenice M. C.; JULIÃO, Elionaldo F. A educação na prisão como política pública: entre desafios e tarefas. Educ. Real., Porto Alegre, v. 38, n. 1, p. 51-69, Mar. 2013. Available from: http://www.scielo.br/scielo.php?script=sci_arttext\&pid=S2175$\underline{62362013000100005 \& \operatorname{lng}=\mathrm{en} \& \mathrm{nrm}=\mathrm{iso}}$. access on 18 nov. 2017.

OLIVEIRA, G. M. (Org.). Declaração Universal dos Direitos Linguísticos: novas perspectivas em política linguística. Campinas, SP: Mercado das Letras, Associação de Leitura do Brasil; Florianópolis, SC: IPOL, 2003.

OLIVEIRA, Odete Maria de. Prisão: um paradoxo social. Florianópolis: Editora da UFSC, 1984. 
ONU. Declaração Universal dos Direitos Humanos. Disponível: https://nacoesunidas.org/direitoshumanos/declaracao/

ORLANDI, Eni de L. P. (Org.). Política linguística no Brasil. Campinas: Pontes, 2007.

SANTOS, José Jackson Reis dos. Especificidades dos saberes para a docência na educação de pessoas jovens e adultas. Revista Práxis Educacional, Vitória da Conquista, v. 6, n. 8, jan./jun. 2010. Disponível em: https://periodicos2.uesb.br/index.php/praxis/article/view/623. Acesso em: 13 nov. 2017.

SANTOS, Leonor Werneck. Análise e produção de textos. São Paulo: Contexto, 2013.

STREEET, Brian. Abordagens alternativas ao letramento e desenvolvimento. Paper entregue após a Teleconferência Unesco Brasil sobre Letramento e Diversidade, 2003. Disponível em: http://telecongresso.sesi.org.br. Acesso em 07 de março de 2018.

TEIXEIRA, Wagner Barros. Presença e funções do espanhol no Alto Rio Negro/AM: considerações políticas e históricas. Rio de Janeiro, 2014. Tese de Doutorado apresentada à coordenação do Programa de Doutorado em Letras Neolatinas da Faculdade de Letras da UFRJ, Rio de Janeiro, 2014, 355 fls.

UNESCO, Educando para a liberdade: trajetória, debates e proposições de um projeto para a educação nas prisões brasileiras. Ministério da Educação, Ministério da Justiça, Brasília: UNESCO, 2006.

YIN, Robert K. Estudo de caso: planejamento e métodos. Porto Alegre: Bookman, 2001.

\section{$\underline{\text { SOBRE AS AUTORAS }}$}

\section{Fabiane Maia Garcia}

Doutora em Educação pela Universidade de Minho (UMINHO). Mestra em Sociedade e Cultura na Amazônia (UFAM). Professora do Programa de Pós-graduação em Educação da UFAM. Membro do Grupos de pesquisa Grupo Interdisciplinar de Pesquisa em Educação na América Latina (EDUCAL/UNILA) e do Grupo de Pesquisa Gênero, Trabalho e Educação (UFAM). E-mail: fgarcia@ufam.edu.br

\section{Thays Coelho de Araújo}

Mestranda em Estudos da Linguagem pelo Programa de Pós-graduação em Letras da Universidade Federal do Amazonas (UFAM). Professora da UFAM. Membro do Grupo de Pesquisa Observatório de Línguas. E-mail: thaisestald@gmail.com

\section{Poline Melo dos Santos}

Graduada em Pedagogia pela Universidade Federal do Amazonas (UFAM). E-mail: poline294@gmail.com 